\title{
Sowing depth of annual ryegrass seed on different substrates as a vigor test ${ }^{1}$
}

\author{
Roberto Caetano de Oliveira ${ }^{2}$ (D), Carlos Eduardo da Silva Pedroso ${ }^{2 *(D)}$, \\ Vanessa Nogueira Soares² ${ }^{\text {ID }}$, Lílian Madruga de Tunes², Géri Eduardo \\ Meneghello (iD, Carlos Henrique Silveira Rabelo (iD) ${ }^{2}$
}

\begin{abstract}
Annual ryegrass seeds having low physiological quality can lead to the formation of pastures with undesirable plant stands for soil cover and forage utilization pastures. Thus, the objective of this study was proposing a vigor test to classify annual ryegrass seeds. For that, different sowing depths $(0.5,1.0,1.5,2.0,2.5$ and $3.0 \mathrm{~cm})$ over three substrates (sand, coconut fiber, and carbonized rice husk) were tested to differentiate the physiological quality of four seed lots of annual ryegrass cv. BRS Ponteio having similarities in germination and moisture. The seed lots were classified according to vigor through the field seedling emergence (FSE), 1,000-seeds weight, saturated salt accelerated aging, and germination first count. The $2.5 \mathrm{~cm}$ of sand sowing depth and $3.0 \mathrm{~cm}$ of coconut fiber sowing depth provided separation of seed lots in similar groups of those reported to FSE test through the seedling emergence and speed of seedling emergence tests.
\end{abstract}

Index terms: coconut fiber, Lolium multiflorum Lam., seedling vigor, sowing depth.

\section{Profundidade de semeadura de sementes de azevém anual em diferentes substratos como um teste de vigor}

\begin{abstract}
RESUMO - Sementes de azevém com baixa qualidade fisiológica têm resultado em pastagens com inadequado estande de plantas para a cobertura do solo e, sobretudo, para a exploração forrageira. Neste sentido, o presente trabalho teve como objetivo propor um teste de vigor para sementes de azevém anual. Foram testadas profundidades de semeadura $(0,5 ; 1,0 ; 1,5$; 2,$0 ; 2,5$ e $3 \mathrm{~cm}$ ) em três substratos (areia, fibra de coco e casca de arroz carbonizada) para diferenciar a qualidade fisiológica de quatro lotes de sementes da cultivar BRS Ponteio que apresentaram semelhança no teste de germinação e umidade. Os lotes foram classificados quanto ao vigor pelos testes de emergência em campo, peso de mil sementes, envelhecimento acelerado e primeira contagem da germinação. A profundidade de semeadura em substratos de areia e fibra de coco permitiu a determinação do vigor em sementes de azevém anual (de maneira similar ao observado no teste de germinação no campo), pela porcentagem de emergência e pelo índice de velocidade de emergência de plântulas semeadas em areia a 2,5 e em fibra de coco a 3,0 $\mathrm{cm}$ de profundidade de semeadura.
\end{abstract}

Termos para indexação: emergência de plântulas, Lolium multiflorum Lam., qualidade fisiológica, semente forrageira.

\section{Introduction}

Annual ryegrass can be considered the most important winter-season forage for livestock in Southern Brazil, by supplying continuous fodder of high nutritive value during the food shortage period (Flores et al., 2008). However, annual ryegrass seeds are small and have dormancy (Stanisavljević et al., 2011), as reported for other forage seeds. Consequently, they are generally difficult to germinate under adverse field conditions (Stanisavljević et al., 2011), and then, can lead to the formation of pastures with undesirable plant stands for soil cover and forage utilization.

Seed comprises the main agricultural input and the way for technological changes inside the farm. Thus, tests examining germination and seed vigor are essential to predict sowing performance and ensure rapid stand

${ }^{1}$ Submitted on 08/20/2018. Accepted for publication on 03/24/2019.

${ }^{2}$ Universidade Federal de Pelotas, Departamento de Fitotecnia, Capão do Leão, 96050-500 - Rio Grande do Sul, Brasil.

*Corresponding author <cepedroso@terra.com.br> 
establishment (Wang et al., 2004). Germination test has the goal to estimate the germination potential of a seed lot; such response is used to compare the quality of different lots (Brasil, 2009). However, germination percentages of seed lots provide only limited information about the sowing potential because laboratory conditions are not always representative of field conditions (Boligon et al., 2011). In this regard, vigor tests have been proposed to rank seed lots with different physiological quality by providing higher sensitive index and predicting sowing potential than do germination test (MarcosFilho, 2015). Although vigor tests to rank seed lots of other forage species has been proposed (Wang et al., 2004), little knowledge is available on seed vigor tests for annual ryegrass.

Furthermore, seed sowing depth and substrate upon which the seed is placed are known to influence seedling emergence (Melo et al., 2017; Xiao et al., 2010). Seedling emergence is the single most important phenological event that influences the success of an annual plant establishment (Forcella et al., 2000). Based on that assumption, we hypothesized that combining different seed sowing depths and substrates may challenge seedling emergence and its features, and hence a robust vigor test can be proposed to rank annual ryegrass seeds, since this information is lacking in the literature.

\section{Material and Methods}

On March 2014 to March 2015 the current study was carried out at the Department of Plant Science of the Universidade Federal de Pelotas (UFPel), Pelotas - RS (31 ${ }^{\circ} 76$ '54" S and 52 33'76" W, altitude $7 \mathrm{~m}$ ), Brazil. Annual ryegrass (Lolium multiflorum Lam.) cv. BRS Ponteio was used in the tests, being represented by four seed lots, of which two lots (basic class) were acquired by Empresa Brasileira de Pesquisa Agropecuária (EMBRAPA; Clima Temperado, Pelotas, Brazil), and two lots (S2 class) were owned by local trade. All seed lots were kept at $10{ }^{\circ} \mathrm{C}$ for three months before use.

Seed water content was determined through the oven method $\left(105 \pm 3{ }^{\circ} \mathrm{C}\right.$ for $24 \mathrm{~h}$ ) according to the Rules for Seed Testing (Brasil, 2009). For this determination, six statistical replications of 2-g seeds (each replication was composed of two test-samples) from each lot were used, and the overall mean was $10.4 \pm 0.20 \%$.

To determine the 1,000-seeds weight, eight sample groups of 100 seeds each were selected and weighed in an electronic balance with $0.0001 \mathrm{~g}$ accuracy (model AY220, Marte ${ }^{\circledR}$, São Paulo, SP, Brazil), and then the weight was extrapolated to that of 1,000 seeds; four replications were used.

Germination was evaluated through four replications of 50 seeds per seed lot using a plastic box $(11 \mathrm{~cm} \times 11 \mathrm{~cm} \times 3.5 \mathrm{~cm})$.
Seeds were sowed in rolls of paper toweling moistened with a water weight 2.5 -fold higher than the dry paper weight, at $20^{\circ} \mathrm{C}$. On day 14 after seed sowing, normal seedlings having a coleoptile at least $0.5 \mathrm{~cm}$ long were counted according to the Rules for Seed Testing (Brasil, 2009). Results were expressed as mean percentages of normal seedlings for each lot. Germination first count (GFC) test was performed concomitantly with the germination test; the percentage of normal seedlings was recorded on day 5 after seed sowing, according to Brasil (2009).

Saturated salt accelerated aging (SSAA) was conducted through the distribution of seed samples $(2 \mathrm{~g})$ from each lot in a single layer on a suspended screen within a plastic box $(11 \mathrm{~cm} \times 11 \mathrm{~cm} \times 3.5 \mathrm{~cm})$ containing $40 \mathrm{~mL}$ of saturated $\mathrm{NaCl}$ solution (11 $\mathrm{g} \mathrm{NaCl}$ diluted into $100 \mathrm{~mL}$ of distilled water). The boxes were kept in a BOD chamber at $41^{\circ} \mathrm{C}$ for $48 \mathrm{~h}$ (Tunes et al., 2011), and then the germination test was conducted. The germinated seeds were analyzed on day 5 after sowing with four replications of 50 seeds for each lot. Results were expressed as mean percentages of normal seedlings for each lot.

Field seedling emergence (FSE) was conducted over an Albaqualf soil (A horizon) bed with four replications (block) of 100 seeds. Soil bed was represented by a $1.2 \mathrm{~m}$ long planting furrow, spaced at $10 \mathrm{~cm}$, in which 100 seeds were distributed at a uniform distance for each planting furrow. Seeds were sowed by hand at a depth of $1 \mathrm{~cm}$. Seedlings received spray irrigation according to need, based on climatic conditions during the test (Figure 1). The number of emerged seedlings was recorded on day 21 after seed sowing. The percentage of seedling emergence was calculated to obtain mean values per lot.

Seedling emergence was investigated in different seed sowing depths using sand, coconut fiber (CF), and charcoal rice husk (CRH) as substrates. For each substrate, seed sowing was performed manually on plastic trays at depths of $0.5,1.0$, $1.5,2.0,2.5$ and $3.0 \mathrm{~cm}$. Prior to seed sowing, sand was sifted through a 1.6-mm screen, and then washed and shade-dried. The CF was owned by local trade (Golden Mix ${ }^{\circledR}$, Pelotas, RS, Brazil), and it had a density of 169 g. $\mathrm{L}^{-1}$ and $75.2 \%$ of water retention capacity. The $\mathrm{CF}$ was watered for $48 \mathrm{~h}$ before starting the test. The CRH was obtained by carbonization of the fresh rice husk for a 4-h period; CRH had a density of 223 g.L. $\mathrm{L}^{-1}$ and $54.4 \%$ of water retention capacity. After seed sowing, the plastic trays containing seeds and substrates were incubated in a controlled environment room at $20^{\circ} \mathrm{C}$. Spray irrigation was performed manually, and a same amount of water (equivalent to $60 \%$ of the substrate retention capacity) was added daily. Seedling emergence was evaluated on day 14 after seed sowing; emerged seedlings were considered as those having a coleoptile $\geq 0.5$-cm height over the substrate level. Four replications of 50 
seeds were used for each substrate and sowing depth. Results were expressed as mean percentages of normal seedlings (intact seedlings, which had all of essential structures welldeveloped, complete, and proportional) for each lot.

The speed of seedling emergence (SSE) was assessed since the emergence started. Daily evaluations were performed being all of them in the same time, and the number of emerged seedlings was computed until its stabilization. The SSE was calculated according to the Eq. 1, as follow:

$$
\mathrm{SSE}=\mathrm{n}_{1} / \mathrm{t}_{1}+\mathrm{n}_{2} / \mathrm{t}_{2}+\ldots \mathrm{n}_{\mathrm{n}} / \mathrm{t}_{\mathrm{n}}
$$

where $n_{1}, n_{2}, \ldots n_{n}$ are the number of normal seedlings at times $t_{1}, t_{2}, \ldots t_{n}$ (in days).

The seedling dry weight was assessed when the seedling emergence tests ended. On day 15 after seed sowing, 10 seedlings were randomly taken from each replication of lot, substrate, and sowing depth. The 10-seedlings weight (g) was immediately recorded as-is a fresh weight, and then ovendried at $60{ }^{\circ} \mathrm{C}$ for $72 \mathrm{~h}$ to determine dry weight.
Data from the four treatments (lots of seeds) were submitted to analysis of variance in a completely randomized design, except for data from field seedling emergence, which were analyzed according to randomized blocks. Results of each test were separated for each sowing depth and substrate investigated. Mean values were compared by Scott-Knott test $(\mathrm{P} \leq 0.05)$ using the WinStat software program (v. 2.0). Additionally, Pearson's correlation among laboratory and field tests with seedling emergence, SSE, and 10-seedlings dry weight were calculated.

\section{Results and Discussion}

Data from germination test indicated no difference $(\mathrm{p}>$ 0.05 ) for the four seed lots, which had germination ranging 76$77 \%$ (Table 1). The germination percentages of annual ryegrass seeds assessed in this study are commercially acceptable in Brazil ( $\geq 70 \%$ ), according to the Normative Instruction no. 44 , Nov 22, 2016, Brasil (2016). Since germination percentages

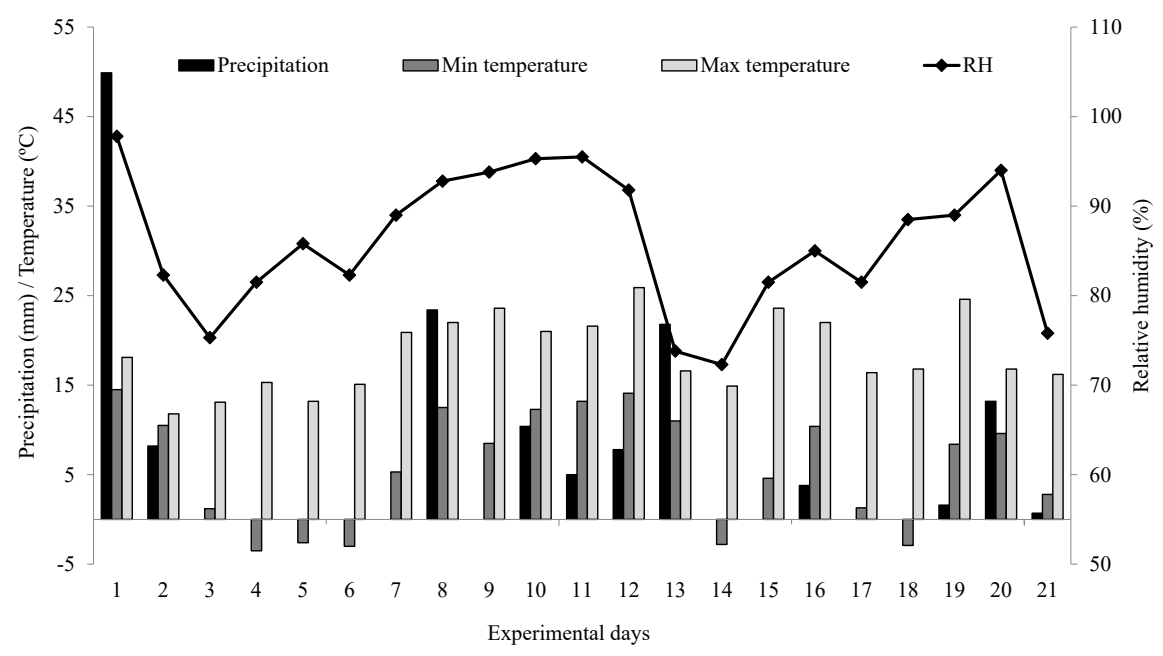

Figure 1. Daily precipitation, temperature (min. and max.) and relative humidity of the air from July 23,2014 to August 12 , 2014 in the city of Pelotas, Southern Brazil.

Table 1. Mean values of moisture, germination, 1,000-seeds weight, germination first count (GFC), saturated salt accelerated aging (SSAA), and field seedling emergence of four seed lots of annual ryegrass cv. BRS Ponteio.

\begin{tabular}{cccccc}
\hline Lots & $\begin{array}{c}\text { Germination } \\
(\%)\end{array}$ & $\begin{array}{c}\text { Seed weight } \\
(\mathrm{g})\end{array}$ & GFC & SSAA & Seedling emergence \\
\hline L1 & 77 & $2.20 \mathrm{a}$ & $72.0 \mathrm{a}$ & $72.0 \mathrm{a}$ & $71.0 \mathrm{a}$ \\
L2 & 76 & $1.92 \mathrm{~b}$ & $71.0 \mathrm{a}$ & $58.0 \mathrm{~b}$ & $64.0 \mathrm{~b}$ \\
L3 & 76 & $1.94 \mathrm{~b}$ & $59.0 \mathrm{c}$ & $59.0 \mathrm{~b}$ & $75.0 \mathrm{a}$ \\
L4 & 77 & $1.85 \mathrm{~b}$ & $65.0 \mathrm{~b}$ & $52.0 \mathrm{c}$ & $66.0 \mathrm{~b}$ \\
\hline C.V. (\%) & $3.63{ }^{\mathrm{ns}}$ & 2.56 & 5.28 & 6.08 & 7.62 \\
\hline
\end{tabular}

Means in the same column with different lowercase letters differed (Scott-Knott test, $\mathrm{p} \leq 0.05)$; ns = non-significant; C.V. = coefficient of variation. 
were similar to each other and higher than those required to market, seed lots can be only separated in physiological quality groups through the vigor tests (Marcos-Filho, 2015; Milošević et al., 2010). In this regard, the test measuring the seed weight provided to rank two groups of seed lots, in which L1 was superior to others $(p \leq 0.05)$. Weight is an important seed feature because is vigor-related, and hence higher seed weight is often correlated with higher vigor (Carvalho and Nakagawa, 2000). Conversely, a robust test might identify more seed lot groups than a weak test (Wang et al., 2004). Thus, both GFC and SSAA tests allowed ranking three seed lot groups. For instance, GFC test ranked the seed lots L1 and L2 as having higher quality, while L3 was the worst $(\mathrm{p} \leq 0.05)$. However, the seed lot L1 was ranked with better quality $(p \leq 0.05)$ followed by L2 and L3, through the SSAA test. Differences in ranking of seed lots based on GFC and SSAA tests likely arises from the optimal temperature and humidity conditions in which GFC is assessed, whereas the SSAA is performed after seed exposure to the high temperature and humidity.

Overall, laboratory tests were sensitive, but inconsistent, to detect better seed lots in agreement with the FSE test, which ranked L1 and L3 as those with higher quality ( $\mathrm{p} \leq 0.05$; Table 1). Laboratory tests are widely used to examine seed physiological quality, but they do not predict the emergence potential and seedlings growth in the field in most cases (Wang et al., 2004). Therefore, the FSE was assumed to be the most indicated and suitable test to rank seed lots because it takes into account field conditions, and hence, can be applied on farm-level. This assumption was based on the fact that seedling emergence is probably the sole most important phenological event influencing the success of an annual plant establishment (Forcella et al., 2000).

After grouping seed lots of annual ryegrass by quality according to the laboratory and FSE tests, the effects of different seed sowing depths and substrates on seedling features and their correlation with laboratory and field tests were examined. The current study is the first one proposing a vigor test to rank annual ryegrass seeds based on the utilization of different seed sowing depths and substrates. Seedling emergence provided a sensitive test to rank seed lots of annual ryegrass ( $\leq 0.05) ; 1.5$ and $2.5 \mathrm{~cm}$ of sand sowing depths, and $1.0,2.5$, and $3.0 \mathrm{~cm}$ of CF sowing depths indicated there was one group of higher physiological quality (L1 and L3) and other of lower quality (L2 and L4; Table 2). It is worth noting that seedling emergence test is one of the most important tests for determining seed vigor, so that it is very helpful to rank seed lots (Marcos-Filho, 2015). In contrast, CRH sowing depths ranging $1.5-3.0 \mathrm{~cm}$ indicated there were two or three seed groups, by which L1 had always the best quality $(\mathrm{p} \leq 0.05)$. Differences reported in ranking seed lots by using the CRH substrate compared to sand and CF likely arises from differences in the physical support upon which the seed is placed, because the preservation of the appropriate conditions for seed germination and seedling growth may be affected as well (Martins et al., 2013).

Table 2. Effect of different seed sowing depths and substrates (sand, coconut fiber (CF), and charcoal rice husk (CRH)) on the seedling emergence (\%) of four seed lots of annual ryegrass cv. BRS Ponteio.

\begin{tabular}{|c|c|c|c|c|c|c|c|}
\hline \multirow{2}{*}{ Substrate } & \multirow{2}{*}{ Lots } & \multicolumn{6}{|c|}{ Seed sowing depth $(\mathrm{cm})$} \\
\hline & & 0.5 & 1.0 & 1.5 & 2.0 & 2.5 & 3.0 \\
\hline \multirow{4}{*}{ Sand } & L1 & $68.0 \mathrm{a}$ & 64.5 & $72.5 \mathrm{a}$ & $73.0 \mathrm{a}$ & $69.0 \mathrm{a}$ & 60.5 \\
\hline & $\mathrm{L} 2$ & $63.0 \mathrm{a}$ & 64.0 & $54.0 \mathrm{~b}$ & $57.0 \mathrm{~b}$ & $56.0 \mathrm{~b}$ & 52.5 \\
\hline & L3 & $69.0 \mathrm{a}$ & 61.0 & $62.5 \mathrm{a}$ & $59.5 \mathrm{~b}$ & $66.0 \mathrm{a}$ & 50.0 \\
\hline & $\mathrm{L} 4$ & $55.0 \mathrm{~b}$ & 59.5 & $51.0 \mathrm{~b}$ & $52.5 \mathrm{~b}$ & $57.0 \mathrm{~b}$ & 48.5 \\
\hline \multirow{5}{*}{$\mathrm{CF}$} & & & ns & & & & ns \\
\hline & L1 & 77.5 & $73.5 \mathrm{a}$ & 69.0 & $72.0 \mathrm{a}$ & $72.0 \mathrm{a}$ & $74.0 \mathrm{a}$ \\
\hline & $\mathrm{L} 2$ & 65.0 & $65.5 \mathrm{~b}$ & 61.5 & $64.0 \mathrm{a}$ & $60.5 \mathrm{~b}$ & $58.0 \mathrm{~b}$ \\
\hline & L3 & 74.0 & $71.0 \mathrm{a}$ & 68.0 & $68.0 \mathrm{a}$ & $72.0 \mathrm{a}$ & $69.5 \mathrm{a}$ \\
\hline & L4 & 70.5 & $58.5 \mathrm{~b}$ & 55.0 & $56.0 \mathrm{~b}$ & $59.0 \mathrm{~b}$ & $60.0 \mathrm{~b}$ \\
\hline & & ns & & ns & & & \\
\hline \multirow{4}{*}{$\mathrm{CRH}$} & L1 & 71.0 & $68.0 \mathrm{a}$ & $70.0 \mathrm{a}$ & $65.0 \mathrm{a}$ & $70.0 \mathrm{a}$ & $60.0 \mathrm{a}$ \\
\hline & $\mathrm{L} 2$ & 64.5 & $53.5 \mathrm{~b}$ & $56.0 \mathrm{~b}$ & $50.0 \mathrm{~b}$ & $48.5 \mathrm{~b}$ & $41.5 \mathrm{~b}$ \\
\hline & L3 & 60.5 & $59.0 \mathrm{~b}$ & $51.5 \mathrm{~b}$ & $40.0 \mathrm{c}$ & $38.0 \mathrm{~b}$ & $46.0 \mathrm{~b}$ \\
\hline & L4 & 67.5 & $67.5 \mathrm{a}$ & $59.0 \mathrm{~b}$ & $51.5 \mathrm{~b}$ & $39.5 \mathrm{~b}$ & $43.0 \mathrm{~b}$ \\
\hline & & $\mathrm{ns}$ & & & & & \\
\hline \multicolumn{2}{|c|}{ C.V. (\%) } & 9.81 & 10.9 & 12.9 & 11.7 & 12.4 & 14.8 \\
\hline
\end{tabular}

Means in the same column for each type of substrate with different lowercase letters differed (Scott-Knott test, $\mathrm{p} \leq 0.05$ ); ns $=$ non-significant; C.V. $=$ coefficient of variation. 
The SSE test was sensitive to rank seed lots $(p \leq 0.05)$ in one group of high quality (L1 and L3) and other of low quality (L2 and L4) only by using $2.5 \mathrm{~cm}$ of sand sowing depth and $3.0 \mathrm{~cm}$ of CF sowing depth (Table 3 ). The SSE is an important indicator of seed physiological quality and can be considered as a more sensitive index of seed performance than germination percentage (Marcos-Filho, 2015). Rapid germination is an important component of the seed vigor concept because it often means a more rapid seedling emergence in the field (Marcos-Filho, 2015). Through the SSE test, CRH sowing depths ranging $1.5-3.0 \mathrm{~cm}$ revealed that $\mathrm{L} 1$ was superior in quality to other seed lots $(\mathrm{p} \leq 0.05)$, which is in agreement with the laboratory tests but not in comparison with the FSE test. The causes for such inconsistence in ranking seed lots comparing different substrates may arise from differences in preservation of the appropriate conditions of physiological quality of seeds for germination, as discussed earlier. For last, the 10 -seedling dry weight test ranked the $\mathrm{L} 1$ as having the highest $(\mathrm{p} \leq 0.05)$ quality by using $1.5 \mathrm{~cm}$ of sand sowing depth (Table 4). Moreover, two groups (high quality, L1 and L2; and low quality, L3 and L4) were separated in the 0.5, 1.5 , and $3.0 \mathrm{~cm}$ of CF sowing depths $(\mathrm{p} \leq 0.05)$. The 1.5 and $3.0 \mathrm{~cm}$ of $\mathrm{CRH}$ sowing depths indicated the L1 as having the higher quality $(p \leq 0.05)$. Overall, some tests based on seedling performance through combinations of sowing depths and specific substrates reported that L1 was the seed lot having the high physiological quality for seed germination, which is in accordance with the laboratory tests. However, laboratory tests do not always predict the emergence potential and seedlings growth in the field as discussed earlier (Wang et al., 2004). Thus, combinations of sowing depths and substrates that indicated similar ranking of seed lots to the FSE test might be more suitable to predict seedling performance in the field.

Coefficients of Pearson's correlation between FSE and seedling emergence under laboratory conditions were higher ( $\mathrm{p} \leq 0.01$ ) with 1.5 and $2.5 \mathrm{~cm}$ of sand sowing depths ( 0.76 and 0.85 , respectively), and also $2.5 \mathrm{~cm}$ of CF sowing depth ( 0.85 ; Table 5). Although seedling emergence under laboratory conditions do not predict seedling performance in the field in most cases, those test is one of the most common used for ranking seed lots (Marcos-Filho, 2015), and can be helpful to indicate seed physiological quality. However, only specific combinations of sowing depths and substrates were found to have a high coefficient of Pearson's correlation. Notably, the substrate represents the physical support upon which the seed is placed with the function of offering and preserving the appropriate conditions for seed germination and seedling growth (Martins et al., 2013). Thus, responses on seed

Table 3. Effect of different seed sowing depths and substrates (sand, coconut fiber (CF), and charcoal rice husk (CRH)) on the speed of seedling emergence (index) of four seed lots of annual ryegrass cv. BRS Ponteio.

\begin{tabular}{|c|c|c|c|c|c|c|c|}
\hline \multirow{2}{*}{ Substrate } & \multirow{2}{*}{ Lots } & \multicolumn{6}{|c|}{ Seed sowing depth $(\mathrm{cm})$} \\
\hline & & 0.5 & 1.0 & 1.5 & 2.0 & 2.5 & 3.0 \\
\hline \multirow{4}{*}{ Sand } & L1 & $4.69 \mathrm{a}$ & 4.32 & $4.76 \mathrm{a}$ & $4.69 \mathrm{a}$ & $4.10 \mathrm{a}$ & $3.45 \mathrm{a}$ \\
\hline & $\mathrm{L} 2$ & $4.09 \mathrm{a}$ & 4.49 & $3.35 \mathrm{~b}$ & $3.44 \mathrm{~b}$ & $3.42 \mathrm{~b}$ & $3.05 \mathrm{a}$ \\
\hline & L3 & $4.06 \mathrm{a}$ & 3.94 & $3.79 \mathrm{~b}$ & $3.51 \mathrm{~b}$ & $3.68 \mathrm{a}$ & $2.65 \mathrm{~b}$ \\
\hline & $\mathrm{L} 4$ & $3.31 \mathrm{~b}$ & 3.38 & $2.83 \mathrm{~b}$ & $2.86 \mathrm{~b}$ & $2.90 \mathrm{~b}$ & $2.38 \mathrm{~b}$ \\
\hline \multicolumn{8}{|c|}{ ns } \\
\hline \multirow{4}{*}{$\mathrm{CF}$} & $\mathrm{L} 1$ & $6.17 \mathrm{a}$ & $5.64 \mathrm{a}$ & $4.99 \mathrm{a}$ & $5.13 \mathrm{a}$ & $5.05 \mathrm{a}$ & $4.91 \mathrm{a}$ \\
\hline & $\mathrm{L} 2$ & $5.35 \mathrm{~b}$ & $5.11 \mathrm{a}$ & $4.48 \mathrm{a}$ & $4.67 \mathrm{a}$ & $4.40 \mathrm{a}$ & $3.92 \mathrm{~b}$ \\
\hline & L3 & $5.41 \mathrm{~b}$ & $5.02 \mathrm{a}$ & $4.49 \mathrm{a}$ & $4.51 \mathrm{a}$ & $4.69 \mathrm{a}$ & $4.31 \mathrm{a}$ \\
\hline & L4 & $4.66 \mathrm{~b}$ & $3.66 \mathrm{~b}$ & $3.36 \mathrm{~b}$ & $3.36 \mathrm{~b}$ & $3.50 \mathrm{~b}$ & $3.33 \mathrm{~b}$ \\
\hline \multirow{5}{*}{$\mathrm{CRH}$} & L1 & 4.24 & 4.35 & $4.14 \mathrm{a}$ & $3.67 \mathrm{a}$ & $4.04 \mathrm{a}$ & $3.41 \mathrm{a}$ \\
\hline & L2 & 3.76 & 3.54 & $3.48 \mathrm{~b}$ & $2.88 \mathrm{~b}$ & $2.71 \mathrm{~b}$ & $2.43 \mathrm{~b}$ \\
\hline & L3 & 3.44 & 3.25 & $2.83 \mathrm{~b}$ & $2.29 \mathrm{~b}$ & $1.90 \mathrm{c}$ & $2.50 \mathrm{~b}$ \\
\hline & L4 & 3.73 & 3.56 & $3.08 \mathrm{~b}$ & $2.74 \mathrm{~b}$ & $2.01 \mathrm{c}$ & $2.20 \mathrm{~b}$ \\
\hline & & $\mathrm{ns}$ & ns & & & & \\
\hline \multicolumn{2}{|c|}{ C.V. $(\%)$} & 13.1 & 14.9 & 17.0 & 14.1 & 14.7 & 16.8 \\
\hline
\end{tabular}

Means in the same column for each type of substrate with different lowercase letters differed (Scott-Knott test, $\mathrm{p} \leq 0.05)$; ns $=$ non-significant; C.V. $=$ coefficient of variation. 
Table 4. Effect of different seed sowing depths and substrates (sand, coconut fiber (CF), and charcoal rice husk (CRH)) on the 10-seedlings dry weight (mg) of four seed lots of annual ryegrass cv. BRS Ponteio.

\begin{tabular}{|c|c|c|c|c|c|c|c|}
\hline \multirow{2}{*}{ Substrate } & \multirow{2}{*}{ Lots } & \multicolumn{6}{|c|}{ Seed sowing depth $(\mathrm{cm})$} \\
\hline & & 0.5 & 1.0 & 1.5 & 2.0 & 2.5 & 3.0 \\
\hline \multirow{4}{*}{ Sand } & L1 & $11.0 \mathrm{a}$ & 10.0 & $11.7 \mathrm{a}$ & 8.90 & 10.3 & 9.30 \\
\hline & L2 & $7.70 \mathrm{~b}$ & 9.60 & $9.00 \mathrm{~b}$ & 8.50 & 10.5 & 9.30 \\
\hline & L3 & $9.00 \mathrm{~b}$ & 9.90 & $9.10 \mathrm{~b}$ & 8.90 & 7.50 & 9.20 \\
\hline & L4 & $10.7 \mathrm{a}$ & 10.3 & $8.50 \mathrm{~b}$ & 8.10 & 9.10 & 9.30 \\
\hline & & & ns & & ns & ns & ns \\
\hline \multirow{4}{*}{$\mathrm{CF}$} & L1 & $14.7 \mathrm{a}$ & 12.5 & $13.3 \mathrm{a}$ & 14.3 & 13.5 & $14.5 \mathrm{a}$ \\
\hline & $\mathrm{L} 2$ & $13.7 \mathrm{a}$ & 12.5 & $13.2 \mathrm{a}$ & 14.1 & 11.7 & $12.7 \mathrm{a}$ \\
\hline & L3 & $11.4 \mathrm{~b}$ & 12.5 & $11.0 \mathrm{~b}$ & 11.6 & 12.5 & $11.1 \mathrm{~b}$ \\
\hline & L4 & $10.7 \mathrm{~b}$ & 10.9 & $11.3 \mathrm{~b}$ & 12.3 & 12.1 & $11.4 \mathrm{~b}$ \\
\hline & & & ns & & ns & ns & \\
\hline \multirow{4}{*}{$\mathrm{CRH}$} & L1 & 11.2 & $12.2 \mathrm{a}$ & $13.2 \mathrm{a}$ & 13.1 & 12.6 & $12.1 \mathrm{a}$ \\
\hline & L2 & 10.8 & $11.2 \mathrm{a}$ & $9.70 \mathrm{~b}$ & 10.2 & 10.5 & $10.7 \mathrm{~b}$ \\
\hline & L3 & 9.90 & $9.90 \mathrm{~b}$ & $9.10 \mathrm{~b}$ & 10.9 & 10.3 & $10.2 \mathrm{~b}$ \\
\hline & L4 & 10.4 & $8.50 \mathrm{~b}$ & $9.20 \mathrm{~b}$ & 8.90 & 10.5 & $9.40 \mathrm{~b}$ \\
\hline & ns & & & $\mathrm{ns}$ & ns & \\
\hline \multicolumn{2}{|c|}{ C.V. $(\%)$} & 14.9 & 12.4 & 11.1 & 13.2 & 14.3 & 14.9 \\
\hline
\end{tabular}

Means in the same column for each type of substrate with different lowercase letters differed (Scott-Knott test, $\mathrm{p} \leq 0.05)$; ns $=$ non-significant; C.V. $=$ coefficient of variation.

Table 5. Pearson's correlation ( $\mathrm{r}$ ) between 1,000-seed weight, germination first count (GFC), saturated salt accelerated aging (SSAA), and field seedling emergence with the seedling emergence in different seed sowing depths and substrates for annual ryegrass cv. BRS Ponteio.

\begin{tabular}{|c|c|c|c|c|c|}
\hline Substrate & Depth $(\mathrm{cm})$ & Seed weight & GFC & SSAA & Seedling emergence \\
\hline \multirow{6}{*}{ Sand } & 0.5 & $0.60 *$ & $0.30 \mathrm{~ns}$ & $0.66 * *$ & $0.81 * *$ \\
\hline & 1.0 & $0.41 \mathrm{~ns}$ & $0.64 * *$ & $0.50 \mathrm{~ns}$ & $0.44 \mathrm{~ns}$ \\
\hline & 1.5 & $0.84 * *$ & $0.42 \mathrm{~ns}$ & $0.84 * *$ & $0.76 * *$ \\
\hline & 2.0 & $0.88 * *$ & $0.58 *$ & $0.86 * *$ & $0.61 *$ \\
\hline & 2.5 & $0.72 * *$ & $0.26 \mathrm{~ns}$ & $0.74 * *$ & $0.85 * *$ \\
\hline & 3.0 & $0.66 * *$ & $0.67 * *$ & $0.65 * *$ & $0.53 * *$ \\
\hline \multirow{6}{*}{$\mathrm{CF}$} & 0.5 & $0.62 * *$ & $0.28 \mathrm{~ns}$ & $0.58 *$ & $0.77 * *$ \\
\hline & 1.0 & $0.69 * *$ & $0.39 \mathrm{~ns}$ & $0.72 * *$ & $0.78 * *$ \\
\hline & 1.5 & $0.65 * *$ & $0.29 \mathrm{~ns}$ & $0.69 * *$ & $0.78 * *$ \\
\hline & 2.0 & $0.69 * *$ & $0.41 \mathrm{~ns}$ & $0.72 * *$ & $0.75 * *$ \\
\hline & 2.5 & $0.60 *$ & $0.21 \mathrm{~ns}$ & $0.64 * *$ & $0.85 * *$ \\
\hline & 3.0 & $0.64 * *$ & $0.28 \mathrm{~ns}$ & $0.70 * *$ & $0.82 * *$ \\
\hline \multirow{6}{*}{$\mathrm{CRH}$} & 0.5 & $0.46 \mathrm{~ns}$ & $0.68 * *$ & $0.49 \mathrm{~ns}$ & $0.22 \mathrm{~ns}$ \\
\hline & 1.0 & $0.45 \mathrm{~ns}$ & $0.42 \mathrm{~ns}$ & $0.41 \mathrm{~ns}$ & $0.45 \mathrm{~ns}$ \\
\hline & 1.5 & $0.68 * *$ & $0.68 * *$ & $0.63 * *$ & $0.30 \mathrm{~ns}$ \\
\hline & 2.0 & $0.71 * *$ & $0.86 * *$ & $0.70 * *$ & $0.16 \mathrm{~ns}$ \\
\hline & 2.5 & $0.90 * *$ & $0.83 * *$ & $0.91 * *$ & $0.29 \mathrm{~ns}$ \\
\hline & 3.0 & $0.79 * *$ & $0.53 *$ & $0.84 * *$ & $0.63 * *$ \\
\hline
\end{tabular}

$\mathrm{ns}=$ non-significant; $* \mathrm{p} \leq 0.05 ; * * \mathrm{p} \leq 0.01 ; \mathrm{CF}=$ coconut fiber $(\mathrm{CF}) ; \mathrm{CRH}=$ charcoal rice husk. 
germination and seedling growth can be affected for inherent characteristics of the substrate, such as structure, air space, water retention capacity, and pathogen infestation level (Melo et al., 2017). In this regard, sand has been recommended as a suitable substrate to examine seed lots quality according to the Rules for Seed Testing (Brasil, 2009), which was confirmed in this study for annual ryegrass. Substrates other than sand, such as $\mathrm{CF}$, are used to examine germination and vigor of tree seeds (Duarte et al., 2010; Pinto et al., 2011), but to our knowledge there is no information about CF utilization with annual ryegrass seeds. Thus, the current study showed that the $3.0 \mathrm{~cm}$ of CF sowing depth provided separation of seed lots in one high- and one low-quality group through seedling emergence and SSE responses; these results were similar and well-correlated with FSE. In contrast, the CRH sowing depths ranging $1.5-3.0 \mathrm{~cm}$ indicated there is one seed lot (i.e., L1) with better quality. However, these results were poorly or no correlated with FSE test; thus, CRH is not a suitable substrate for examining annual ryegrass seeds. Good physical properties with no alteration in a short-time, abundance of renewable raw material, and low cost to the producer are the characteristics by which $\mathrm{CF}$ has been recommended for seed investigation (Carrijo et al., 2002).

Furthermore, the majority of laboratory test results were positively correlated with SSE index $(\mathrm{p} \leq 0.05)$, but correlation between FSE and SSE index were higher $(\mathrm{p} \leq 0.01)$ by using $2.5 \mathrm{~cm}$ of sand sowing depth $(0.70)$ and $3.0 \mathrm{~cm}$ of CF sowing depth (0.75; Table 6). As discussed earlier, the SSE index can be considered more sensitive than germination percentage for predicting seed performance (Marcos-Filho, 2015), but the reasons for why only specific combinations of sowing depths and substrates provided high coefficients of Pearson's correlation may be related with substrate features and their influence on the preservation of seed physiological quality. Lastly, we found a positive correlation between 1,000-seed weight and 10 -seedling dry weight $(\mathrm{p} \leq 0.01)$ by using 1.5 $\mathrm{cm}$ of sand sowing depth (0.94), and also the $2.0 \mathrm{~cm}$ of CRH sowing depth (0.92); however, 10-seedling dry weight was poorly $(\leq 0.66 ; p \leq 0.01)$ or no correlated $(p \geq 0.05)$ with FSE (Table 7). Seedling emergence is dependent not only of the energy reserved in the endosperm or cotyledons, but also of seed sowing depth. As known, sowing so deep can prevent germination because seed reserves may be exhausted before the seedling reaches the substrate surface, and therefore, the

Table 6. Pearson's correlation ( $\mathrm{r}$ ) between 1,000-seed weight, germination first count (GFC), saturated salt accelerated aging (SSAA), and field seedling emergence with the speed of seedling emergence (index) in different seed sowing depths and substrates for annual ryegrass $\mathrm{cv}$. BRS Ponteio.

\begin{tabular}{|c|c|c|c|c|c|}
\hline Substrate & Depth $(\mathrm{cm})$ & Seed weight & GFC & SSAA & Seedling emergence \\
\hline \multirow{6}{*}{ Sand } & 0.5 & $0.77 * *$ & $0.57 *$ & $0.83 * *$ & $0.59 *$ \\
\hline & 1.0 & $0.54 *$ & $0.65 * *$ & $0.60 *$ & $0.33 \mathrm{~ns}$ \\
\hline & 1.5 & $0.85 * *$ & $0.49 \mathrm{~ns}$ & $0.86 * *$ & $0.71 * *$ \\
\hline & 2.0 & $0.92 * *$ & $0.62 *$ & $0.92 * *$ & $0.61 *$ \\
\hline & 2.5 & $0.81 * *$ & $0.47 \mathrm{~ns}$ & $0.84 * *$ & $0.70 * *$ \\
\hline & 3.0 & $0.75 * *$ & $0.75 * *$ & $0.74 * *$ & $0.43 \mathrm{~ns}$ \\
\hline \multirow{6}{*}{$\mathrm{CF}$} & 0.5 & $0.78 * *$ & $0.50 *$ & $0.73 * *$ & $0.60 *$ \\
\hline & 1.0 & $0.75 * *$ & $0.51 *$ & $0.77^{* *}$ & $0.59 *$ \\
\hline & 1.5 & $0.75 * *$ & $0.51 *$ & $0.80 * *$ & $0.62 * *$ \\
\hline & 2.0 & $0.73 * *$ & $0.53 *$ & $0.76^{* *}$ & $0.59 *$ \\
\hline & 2.5 & $0.73 * *$ & $0.43 \mathrm{~ns}$ & $0.76 * *$ & $0.66 * *$ \\
\hline & 3.0 & $0.80 * *$ & $0.46 \mathrm{~ns}$ & $0.85 * *$ & $0.75 * *$ \\
\hline \multirow{6}{*}{$\mathrm{CRH}$} & 0.5 & $0.55 *$ & $0.73 * *$ & $0.60 *$ & $0.31 \mathrm{~ns}$ \\
\hline & 1.0 & $0.67 * *$ & $0.76 * *$ & $0.64 * *$ & $0.40 \mathrm{~ns}$ \\
\hline & 1.5 & $0.73 * *$ & $0.80 * *$ & $0.68 * *$ & $0.31 \mathrm{~ns}$ \\
\hline & 2.0 & $0.68 * *$ & $0.82 * *$ & $0.71 * *$ & $0.18 \mathrm{~ns}$ \\
\hline & 2.5 & $0.90 * *$ & $0.84 * *$ & $0.90 * *$ & $0.26 \mathrm{~ns}$ \\
\hline & 3.0 & $0.81 * *$ & $0.58 *$ & $0.86 * *$ & $0.60 \mathrm{~ns}$ \\
\hline
\end{tabular}

$\mathrm{ns}=$ non-significant $* \mathrm{p} \leq 0.05 ; * * \mathrm{p} \leq 0.01 ; \mathrm{CF}=$ coconut fiber $(\mathrm{CF}) ; \mathrm{CRH}=$ charcoal rice husk. 
Table 7. Pearson's correlation (r) between 1,000-seed weight, germination first count (GFC), saturated salt accelerated aging (SSAA), and field seedling emergence with the 10-seedlings dry weight in different seed sowing depths and substrates for annual ryegrass $\mathrm{cv}$. BRS Ponteio.

\begin{tabular}{cccccc}
\hline Substrate & Depth $(\mathrm{cm})$ & Seed weight & GFC & SSAA & Seedling emergence \\
\hline \multirow{5}{*}{ Sand } & 0.5 & $0.43 \mathrm{~ns}$ & $0.39 \mathrm{~ns}$ & $0.41 \mathrm{~ns}$ & $0.49 \mathrm{~ns}$ \\
& 1.0 & $0.28 \mathrm{~ns}$ & $0.30 \mathrm{~ns}$ & $0.19 \mathrm{~ns}$ & $0.46 \mathrm{~ns}$ \\
& 1.5 & $0.94 * *$ & $0.64 * *$ & $0.96 * *$ & $0.49 \mathrm{~ns}$ \\
& 2.0 & $0.36 \mathrm{~ns}$ & $0.41 \mathrm{~ns}$ & $0.38 \mathrm{~ns}$ & $0.61 *$ \\
& 2.5 & $0.44 \mathrm{~ns}$ & $0.94 * *$ & $0.45 \mathrm{~ns}$ & $0.00 \mathrm{~ns}$ \\
& 3.0 & $0.23 \mathrm{~ns}$ & $0.44 \mathrm{~ns}$ & $0.25 \mathrm{~ns}$ & $0.45 \mathrm{~ns}$ \\
\hline \multirow{3}{*}{ CF } & 0.5 & $0.77 * *$ & $0.84 * *$ & $0.78 * *$ & $0.27 \mathrm{~ns}$ \\
& 1.0 & $0.46 \mathrm{~ns}$ & $0.46 \mathrm{~ns}$ & $0.47 \mathrm{~ns}$ & $0.63 * *$ \\
& 1.5 & $0.61 *$ & $0.77 * *$ & $0.67 * *$ & $0.32 \mathrm{~ns}$ \\
& 2.0 & $0.54 *$ & $0.84 * *$ & $0.54 *$ & $0.23 \mathrm{~ns}$ \\
& 2.5 & $0.58 *$ & $0.43 \mathrm{~ns}$ & $0.53 *$ & $0.66 * *$ \\
& 3.0 & $0.72 * *$ & $0.83 * *$ & $0.71 * *$ & $0.42 \mathrm{~ns}$ \\
\hline \multirow{3}{*}{ CRH } & 0.5 & $0.40 \mathrm{~ns}$ & $0.69 * *$ & $0.43 \mathrm{~ns}$ & $0.34 \mathrm{~ns}$ \\
& 1.0 & $0.73 * *$ & $0.72 * *$ & $0.79 * *$ & $0.37 \mathrm{~ns}$ \\
& 1.5 & $0.84 * *$ & $0.72 * *$ & $0.85 * *$ & $0.45 \mathrm{~ns}$ \\
& 2.0 & $0.92 * *$ & $0.49 \mathrm{~ns}$ & $0.92 * *$ & $0.64 * *$ \\
& 2.5 & $0.78 * *$ & $0.73 * *$ & $0.77 * *$ & $0.51 *$ \\
& 3.0 & $0.64 * *$ & $0.65 * *$ & $0.67 * *$ & $0.51 *$ \\
\hline
\end{tabular}

$\mathrm{ns}=$ non-significant $; \mathrm{p} \leq 0.05 ; * \mathrm{p} \leq 0.01 ; \mathrm{CF}=$ coconut fiber $(\mathrm{CF}) ; \mathrm{CRH}=$ charcoal rice husk.

seedling die (Burmeier et al., 2010; Mou and Sun, 2011). In this regard, annual ryegrass seeds may be sown at $\sim 1 \mathrm{~cm}$ sowing depth to allow vigorous growth under field conditions (Frakes, 1973). However, results of seedling emergence and SSE indicated that $2.5 \mathrm{~cm}$ of sand sowing depth and $3.0 \mathrm{~cm}$ of CF sowing depth were most well-correlated with FSE. Higher sowing depths probably challenged seedling emergence and then the separation of high-quality seed lots of annual ryegrass became possible. Nevertheless, the reasons by which only specific combinations of seed sowing depths and substrates provided a suitable separation of seed lots per physiological quality are not totally understood, and further studies are needed.

\section{Conclusions}

The $2.5 \mathrm{~cm}$ of sand sowing depth and $3.0 \mathrm{~cm}$ of coconut fiber sowing depth allowed to separate high-quality seed lots according to the field seedling emergence test. Moreover, laboratory tests indicated that the L1-seed lot of annual ryegrass was superior to the others.

\section{Acknowledgements}

The authors are grateful to the Coordenação de Aperfeiçoamento de Pessoal de Nivel Superior (CAPES) for financial support.

\section{References}

BOLIGON, A.A.; LÚCIO, A.D.; LOPES, S.J.; CARGNELUTTI FILHO, A.; GARCIA, D.C. Wheat seedling emergence estimated from seed analysis. Scientia Agricola, v.68, p.336-341, 2011. http:// dx.doi.org/10.1590/S0103-90162011000300010.

BRASIL. Ministério da Agricultura, Pecuária e Abastecimento. Regras para análise de sementes. Ministério da Agricultura, Pecuária e Abastecimento. Secretaria de Defesa Agropecuária. Brasília: MAPA, 2009. 395p.

BRASIL. Ministério da Agricultura, Pecuária e Abastecimento. Instrução Normativa n. 44, de 22 de novembro de 2016. Diário Oficial da União, n. 230, seção 1, p.8-11, 2016. Available: http://www.lex. com.br/legis_27233756_INSTRUCAO_NORMATIVA_N_44_ DE_22_NOVEMBRO_DE $\_2016$.aspx. Acessed on June $18^{\overline{\text {th}}}, 2018$. 
BURMEIER, S.; DONATH, T.W.; OTTE, A.; ECKSTEIN, R.L. Rapid burial has differential effects on germination and emergence of smalland large-seeded herbaceous plant species. Seed Science Research, v.20, p.189-200, 2010. https:/www.cambridge.org/core/journals/ seed-science-research/article/rapid-burial-has-differential-effects-ongermination-and-emergence-of-small-and-largeseeded-herbaceousplant-species/E83B3422D740CB0D920AAAD2A326D9CA

CARRIJO, A.O.; LIZ, R.S.; MAKISHIMA, N. Fiber of green coconut shell as an agricultural substrate. Horticultura Brasileira, v.20, p.533535, 2002. http://dx.doi.org/10.1590/S0102-05362002000400003.

CARVALHO, N.M.; NAKAGAWA, J. Sementes: ciência, tecnologia e produção. Jaboticabal: FUNEP, 2000. 588p.

DUARTE, R.F.; SAMPAIO, R.A.; BRANDÃO JÚNIOR, D.S.; FERNANDES, L.A.; SILVA, H.P. Crescimento inicial de Acácia em condicionador formado de fibra de coco e resíduo agregante. Revista Brasileira de Engenharia Agrícola e Ambiental, v.14, p.1176-1185, 2010. http://dx.doi.org/10.1590/S1415-43662010001100007

FLORES, R.A.; DALL'AGNOL, M.; NABINGER, C.; MONTARDO, D.P. Produção de forragem de populações de azevém anual no estado do Rio Grande do Sul. Revista Brasileira de Zootecnia, v.37, p.11681175, 2008. http://dx.doi.org/10.1590/S1516-35982008000700005

FORCELLA, F.; ARNOLD, R.L.B.; SANCHEZ, R.; GHERSA, C.M. Modeling seedling emergence. Field Crops Research, v.67, p.123-139, 2000. https://doi.org/10.1016/S0378-4290(00)00088-5

FRAKES, R.V. The ryegrasses. In: HEATH, M.E.; METCALFE, D.S.; BARNES, R.F. (Eds.). Forages: The Science of Grassland Agriculture. Ames, IA: The Iowa State University Press, 1973. p.307-313.

MARCOS-FILHO, J. Seed vigor testing: an overview of the past, present and future perspective. Scientia Agricola, v.72, p.363-374, 2015. http://dx.doi.org/10.1590/0103-9016-2015-0007

MARTINS, C.C.; BOMBONATO, J.; MARTINS, D.; MARCUSSI, F. Effects of substratum, temperature, and treatments to overcome dormancy on the germination of Fimbristylis dichotoma seeds. Revista de Ciências Agrárias, v.56, p.44-48, 2013. https://repositorio. unesp.br/handle/11449/141210

MELO, P.A.F.R.; CAVALCANTI, M.I.P.; ALVES, E.U.; MARTINS, C.C.; ARAÚJO, L.R. Substrates and temperatures in the germination of Eriotheca gracilipes seeds. Revista Ciência Agronômica, v.48, p.303-309, 2017. http://dx.doi.org/10.5935/1806-6690.20170035
MILOŠEVIĆ, M.; VUJAKOVIĆ, M.; KARAGIĆ, Đ. Vigour tests as indicators of seed viability. Genetika, v.42, p.103-118, 2010. https:// www.researchgate.net/publication/47368062_Vigour_tests_as indicators_of_seed_viability

MOU, X.J.; SUN, Z.G. Effects of sediment burial disturbance on seedling emergence and growth of Suaeda salsa in the tidal wetlands of the Yellow River estuary. Journal of Experimental Marine Biology and Ecology, v.409, p.99-106, 2011. https://link.springer. com/article/10.1007/s11104-010-0542-8

PINTO, J.R.S.; SILVA, M.L.; NOGUEIRA, D.T.S.; DOMBROSKI, J.L.D.; SILVA, A.N. Diferentes tipos de substratos no desenvolvimento inicial de Mimosa caesalpiniifolia Benth. Revista Verde, v.6, p.61-66, 2011. https://www.gvaa.com.br/revista/index. $\mathrm{php} /$ RVADS/article/view/799

STANISAVLJEVIĆ， R.; ĐJOKIĆ, D.; MILENKOVIĆ, J.; ĐUKANOVIĆ, L.; STEVOVIĆ, V.; SIMIĆ, A.; DODIG, D. Seed germination and seedling vigour of Italian ryegrass, cocksfoot and timothy following harvest and storage. Ciência e Agrotecnologia, v.35, p.1141-1148, 2011. http://dx.doi. org/10.1590/S1413-70542011000600014

TUNES, L.M.; PEDROSO, D.C.; BADINELLI, P.G.; TAVARES, L.C.; RUFINO, C.A.; BARROS, A.C.S.A.; MUNIZ, M.F.B. Accelerated aging of ryegrass seeds submitted to saturated salt solution. Ciência Rural, v.41, p.33-37, 2011. http://dx.doi. org/10.1590/S0103-84782011000100006

WANG, Y.R.; YU, L.; NAN, Z.B.; LIU, Y.L. Vigor tests used to rank seed lot quality and predict field emergence in four forage species. Crop Science, v.44, p.535-541, 2004. http://agris.fao.org/agrissearch/search.do?recordID=US201301005389

XIAO, C.; WANG, X.; XIA, J.; LIU, G. The effect of temperature, water level and burial depth on seed germination of Myriophyllum spicatum and Potamogeton malaianus. Aquatic Botany, v.92, p.2832, 2010. https://doi.org/10.1016/j.aquabot.2009.09.004 